\title{
New Ways of Working: How Well are Public Hospital Staff in Nigeria Willing to be Knocked off Their Comfort Zones?
}

\author{
Article by Maclawrence Kolapo Famuyiwa \\ Apapa General Hospital, Apapa, Lagos, Nigeria \\ E-mail: maclawrencefamuyiwa@yahoo.com
}

\begin{abstract}
Purpose: The study examines how welcoming the staff of public hospitals in Nigeria will find the introduction and implementation of new ways of working to satisfy the yearnings of hospital patients for flexibility in receiving health care services in these public hospitals in Nigeria.

Methodology: The study was done in a General Hospital in Nigeria. Staff preference for a way of working was assessed by self-administered and pretested questionnaire. Descriptive statistics to elucidate on the demography of the respondents were done; mean score and standard deviation values were used to examine the variables. Spearman's rho correlation was used to identify the association in the responses.

Findings: The mean score of the traditional ways of working (TWW) and the new ways of working $(\mathrm{NWW})$ were $2.66 \pm 1.27$ and $3.88 \pm 1.73$ respectively and with a negative relationship $(r=-0.926, p<0.001)$.

Research Limitations: More General Hospitals should be involved in new studies for more generalizability.

Practical implications: The benefits of NWW have to be more preached to health workers, since probably because of the fear of the unknown they still prefer their traditional way of working.

Social implications: 'New Ways of Working' will allow patients to access care anywhere, while staff will have the opportunity of combining work and home life better.

Value of the Paper: The introduction and successful implementation of 'New Ways of Working' will be able to meet the satisfaction of both staff and their patients in terms of flexibility to the work and clinic appointments of both respectively.
\end{abstract}

Keywords: New Ways of Working, Traditional Ways of Working, Public Hospitals, Staff, Patients, Satisfaction.

\section{Introduction}

It is now apparent that patients have over the years been clamoring for a change in the way they are given out-patient clinics appointments in public hospitals, where hitherto, no consideration has been given to the peculiarity of the type of work they do or the traffic quagmire the metropolitan lifestyles imposes on their easy movement. These patients, like all other clients of any organization are increasingly expecting to be able to determine when, where and how they wish to receive health care in public hospitals like they wish to conduct business with other organizations (Kotler, Kartajaya \& Setiawan, 2010), Keuning, 2007).

In meeting this obvious challenge many governments in Nigeria, especially the Lagos State Government, has toyed with the idea of enforcing afternoon clinics in which patients not able to attend the conventional morning clinics can suitably attend, but this was resented by health workers giving the excuse of dearth of personnel and the inconveniences this arrangement will bring, not only to their modus vivendi, but also to the state of their own wellness, so the idea was stifled into obscurity.

However, it is expedient that a way has to be fashioned out in which these patients can achieve their agitation for flexibility in their clinic appointments, and the patient can also achieve their desired work flexibility, so a way has to be fashioned out in which these have to 
Texila International Journal of Public Health

Volume 5, Issue 1, Mar 2017

be balanced. The idea of developing 'New Ways of Working' (NWW), as has been effectively implemented in other sectors as well as in some other countries has to be introduced. The UK Department of Health (2010) observed that NWW will lead to increased staff responsibility for the improvement of patients' lots in terms of the services they receive, and this brings to the fore the necessity to build and sustain a capable, flexible workforce to respond effectively and efficiently to the patients and staff needs.

\section{The new ways of working}

'The New Ways of Working' (NWW), has various definitions (Baane, Houtkamp, \& Knotter, 2010; Volberda, Jansen, Tempelaar, \& Heij, 2011). For example, Bijl (2009) defined NWW as a vision whereby recent developments in information technology act as a catalyst for a better design and management of knowledge work. This definition has been established to encompass all other definitions as it includes the four most important focus areas (people, organizations, work environment and technology). Bijl, (2007, 2009) and Blok, Groenesteijn, Schelvis, \& Vink, (2012), all identified four cornerstones of NWW to be:

1. The individual: this includes elements such as motivation and competence (development)

2. The organization: this includes organizational structure, organizational culture and leadership style.

3. The work environment: this includes office space and design.

4. The technology: this includes ICT equipment and support.

\section{The individual and competency (Development)}

Many different skills have been identified to be important to realize NWW, and according to Stam (2011), the most important of these skills are: managing staff, organizing one's own work, commitment, networking, independence, decision-making skills, goal-orientation, communication, flexible behavior and collaboration. And it is when these skills are well developed that NWW can be ensured (Pierick, 2009).

\section{The organization}

Bijl, (2009) and De Leede, and Kraijenbrink, (2014), stated that there are three elements that are closely knitted together within any organization: vision/ambition, organizational structure and organizational culture. Vision and ambition gives the direction the organization intends to tow. It is thus mandatory for the vision and the ambition of the organization to accommodate NWW so as to ensure staff motivation and successful implementation of NWW. This may mean the re-organization of the hospital structures, tending towards a network structure which allows collaborations between different levels of hospital workers with copious use of ICT for self-management, self-organization, enterprise and exchange of information (Bijl, 2009, Kuipers, Amelsvoort, \& Krame, 2010).

Organizational culture is about the correlation between how individuals within the organization want to interact (Bijl, 2009) and how they actually communicate and collaborate with each other (Egmond van, 2010), and leadership plays an important role in this (Egmond van, 2010, Cameron, \& Quinn, (2008) and Keuning, (2007). According to Bijl, (2007, 2009) NWW ensures the need of person-centered leadership, staff support, collaboration, and the realization of connections with staff.

\section{The work environment}

A hybrid organization may be formed with the partial implementation of NWW in which components of a traditional organization are combined with those following NWW (Stam, 2011). NWW however, aims at working methods free of the constraints of time and place, this involves flexible work spaces within the organization customized specifically to various sorts of activities (Bijl, 2007, 2009) and Egmond van, (2010). NWW makes the office to 
become a place where staff gladly physically meet each other there to work together (Bijl, 2009).

\section{The technology}

Introduction of ICT to NWW will help staff to be more productive, more creative and more flexible since this will help the implementation of NWW to be more smooth (Wensing, 2009), will enable collaboration and communication, (Haterd, 2010), and contribute to social cohesion (De Leede, \& Kraijenbrink, 2014).

Bijl (2007) also added that a relationship exists between these four cornerstones of NWW described above, and change or renewal is required in all these four cornerstones of NWW in order to achieve the NWW objective. The proper implementation of NWW involves the emphasis on knowledge work, with an insignificant attention paid to the physical presence of staff at their workplace and the willingness and ability of people in the position of leadership willing to apply NWW so as to encourage motivation and competence. De Leede and Kraijenbrink (2014) outline four important conditions for working according to NWW to achieve positive results, and these are trust between colleagues, trust between employeessupervisors, social cohesion and result-oriented leadership, and they further pinpointed trust and social cohesion as mediators when they demonstrated the result of NWW on an organization's performance. Hence it is helpful for any organization to be able to showcase all benefits and shortcomings that can be attributable to NWW.

Heuver (2015), found out that in the service industry he studied, NWW has a positive impacts on productivity and organizational commitments, but that these impacts vary depending on the component of NWW being studied, he conceded that it is teleworking and the use of information technology that have the most positive impacts. He also established that there was a non-existing correlation between flexibility in work place and in working hours. He further noticed that all these NWW variables except teleworking, were found to improve organizational commitment.

The emphasis NWW places on the result demands a different organization of the work place, the organizational structure and the style of leadership. Additionally, the current technology offers the opportunity to work without the restriction of time or location (Bijl, 2009). The New Ways of Working explores the separation of the constraints of time and place from staff flexibility and the usage of innovative technological developments, resulting in the rendering of a satisfying service to the patient. It is also believed that NWW will offer staff the opportunity to combine work and home life better, enabling them to work with more flexibility, as well as further their personal development (Baane, Houtkamp, \& Knotter, 2010). To effectively achieve NWW it then means that staff will now also be expecting different opportunities than they have ever had, which means a change in the leadership style is inevitable in order for NWW to be accommodated.

NWW is thus important to ensure that patients especially those attending out-patient clinics and seeking specialist consultations in General Hospitals can be in the confines of their offices and homes as well as other places and still be able to receive quality healthcare from their doctors and other hospital staff making use of latest technologies most notably social media such as Facebook, Twitter, Skype, Whatsapp, Oovoo, Join me etc, and this will also ensure that these health workers will also be able to flexibly attend to the health needs of their patients from anywhere without compulsorily needing to be physically present within the hospital premises except when they need to attend to emergency cases. NWW involves an employee successfully juxtaposing his work with the working environment, and the flexibility of the work ambience to suit various sorts of activities (Bijl, 2007; Bijl, 2009; Egmond van, 2010), which often resulting in offices of these employees being mere meeting points for staff and should be designed in such a way that staff gladly physically meet each other there to work together (Bijl, 2009). Stam (2011) stated that NWW can be fully or partially introduced in any organization, a partial implementation leads to a hybrid organization in which there is the combination of the components of a traditional organization with those following NWW. 
Texila International Journal of Public Health

Volume 5, Issue 1, Mar 2017

It is however saddening that despite the obvious advantages that the new ways of working will introduce into patients management and staff satisfaction, it is still a rarity in any public hospitals in Nigeria, and the feasibility of its introduction is further hampered by political and bureaucratic bottle necks and the fear of the unknown that it may have on the hospital staff, since it will be like dislodging them from their comfort zones and expectedly oppositions are to be expected if this new ways of working is to be introduced and implemented in these public hospitals.

These are all the concerns that this study tries to address, so as to add to current knowledge about the effect of NWW on flexibility of staff of public hospitals in Nigeria and how their utilization of new technological developments can aid their working independently of time and place with the view of offering greater service to the patients, to make these hospital patients to appear apparently in charge.

\section{Methods}

\section{Description of the study site}

The study site is a General Hospital in Lagos, Nigeria. It is a multi-specialties hospital consisting of five medical departments: Pediatrics; Obstetrics and Gynecology; Medicine, Surgery, and Community Health. It also has Dental, Physiotherapy, Pharmacy, Laboratory and Nursing departments as well as Health Information Management, Administration and Medical Social Worker departments. It is a 45 bedded hospitals with about 357 members of staff with 25 of these staff belonging to the management cadre, who constituted the Hospital Management Committee, Head of Departments and Head of Sub-units, while the rest can be categorized as non-management staff.

The sample size used in this study was calculated using Taro Yamane formula as follows:

$$
\begin{aligned}
& \mathrm{n}=. \\
& \text { Where } \\
& \mathrm{n}=\text { Sample Size } \\
& \mathrm{N}=\text { Elements of population in this study is } 357 \\
& \mathrm{e}=\text { Error of sampling, in this study is } 10 \text { percent or } 0.10 \text { proportion. }
\end{aligned}
$$

Therefore, substitution in the formula:

$$
\begin{aligned}
\mathrm{n} & =\frac{357}{1+357(0.10)^{2}} \\
& =\mathbf{7 8 . 1 2}
\end{aligned}
$$

The diversity in the professionals available at the study site made it imperative to use a stratified sampling method for this study.

\section{Data collection method}

Questionnaire was used for data collection. I sought for expressions of interest from all surveyed respondents using an introductory letter explaining the aim of the study and the anonymity of the answers, I also gave polite reminders to the respondent three days and repeated again a day to the deadline for the collection of the questionnaire. I designed the study instrument after a rigorous literature review (Memish et al, 2014, WHO, 2013, Gautre, 2013, and Al-Tawfiq \& Memish, 2014). The draft of the questionnaire was validated in 2 steps. Firstly, it was discussed with other senior academics versed in research work to give their expert opinion with respect to its simplicity, relativity and importance. Secondly, a pilot study was conducted by the selection of a small sample of health care professionals $(n=9)$ who gave their opinions on making the questionnaire simpler and shorter. Samples selected for the pilot study took cognizance of all professions working within the hospital studied. The result was used to modify the questionnaire, while ensuring its consistency with the published 
literature (Memish et al, 2014, WHO, 2013, Gautret, 2013, and Al-Tawfiq \& Memish, 2014). I finalized the questionnaire. After a thorough discussion, and subsequently distributed to the participants for their response. The data of the pilot study was not used for the final analysis.

The questionnaire consists of two sections (I and II). The first section consists of questions on demographic information: Gender, Age, Education level, Specialty/Department, and job functions. The second section contains questions on the research question for this study which is the way of working preferred by the staff between their traditional ways of working and the new ways of working intended to be introduced. Responses were evaluated through a 7 point Likert scale of agreement, A score of 1 was given to strongly agree, 2 to agree, 3 to somewhat agree, 4 to neither agree nor disagree, 5 to somewhat disagree, 6 to disagree and 7 to strongly disagree. A mean score of $<5$ was considered as agreement to the statement of the research question while score of $\geq 5$ was taken as disagreement to the statement of the research question.

The primary source of data collection for this study was through the use of validated questionnaire and data was collected in May, 2016.

\section{Reliability and validity of data collection instrument}

\section{Reliability}

The contents of the final questionnaire have a reliability coefficient calculated using SPSS v.20 and the value of Cronbach's alpha (Cronbach, 1951) was 0.81. Cronbach's Alpha values higher than 0.7 is considered reliable (Nunnally, 1978).

\section{Validity}

In order to increase the reliability of this study, a validated questionnaire was used. It has been stated that a validated questionnaire ensures that the research actually measures what it is supposed to measure, this is the extent to which the collection of data, the techniques used and the analysis ensured inter-dependent findings (Saunders, Lewis. Thornhill, Booijl \& Verckens, 2011).

\section{Data analysis method}

The data generated from this study was analysed using SPSS version 20. The descriptive statistics was used for the general characteristics of the study participants. Bivariate relationships between 7-item Likert scales were analysed using Spearman's correlation coefficient ' $r$ ' to measure the correlation, because the measurement scale is ranked (Bryman \& Bell, 2011).

\section{Ethical approval}

Ethical approval was obtained from the management of the hospital before the commencement of the study.

\section{Results}

\section{See table 1}

Table 1 shows that $69.1 \%$ of the respondents were female while $30.9 \%$ were male. This indicates that both male and female sexes are well represented.

\section{See table 2}

Table 2 reveals that $80.4 \%$ of the respondents were between 26 and 50 years age range, out of which $60.3 \%$ are within the age group 41 and 50 years. Those below 25 years and those above 56 years of age were $1.2 \%$ respectively of the respondents. Overall, the data shows that all working age groups are represented. 
Texila International Journal of Public Health

Volume 5, Issue 1, Mar 2017

\section{See table 3}

Table 3 indicates that $65.5 \%$ of the respondents have more than a bachelor degree, with $20.8 \%$ of these group of respondents even having a post-graduate degree, $9.9 \%$ had $\mathrm{OND} / \mathrm{NCE}, 21.0 \%$ had a School of Nursing certificate, and only $2.5 \%$ had a Secondary School certificate, this is a confirmation that the respondents are well educated to understand the questions and provide reliable answers.

\section{See table 4}

The core staff of the hospital, supposedly including the Nurses, Doctors, Dentists, Pharmacists, Physiotherapists and Laboratory workers, as seen in Table 4, constituted $76.6 \%$ of the respondents, an indication that all the core hospital staff needed for the purpose of this research are well represented.

\section{See table 5}

The non-managerial staff among the respondents as revealed in Table 5 constituted $74.1 \%$ of the respondents while $25.9 \%$ were managerial staff which include Head of Departments, Head of subunits and members of Hospital Management Committee, a confirmation of a good representation of all cadres of staff in the sample.

\section{See table 6}

Table 6 shows that on the average the respondents agreed most with the statement that states that hospital workers should be provided with a means of accessing relevant information that will make their work more efficient and effective outside their workplace, with a mean of 1.84 . The standard deviation of 1.08 shows that the study instrument is a good measure of this variable. The mean of Table 6 is 3.88 which shows that the respondents marginally agreed that they will prefer the introduction and the implementation of new ways of working in their hospital, the standard deviation is 1.73 , an indication that the instrument is a good measure of this variable.

\section{See table 7}

Table 7 shows that the respondents mostly agreed that making patients to attend clinics physically for their appointments will be convenient to both staff and patients, and this they believe is their most preferred component of their traditional ways of working with a mean of 2.41 , and a standard deviation of 1.36, an indication of the study instrument being a good measure of the variable. The mean of Table 2 also shows that on the average that the respondents agreed that they have a high preference for their traditional ways of working.

Furthermore, the Spearman's correlation test $(\mathrm{r}=-0.926, \mathrm{p}<0.001)$ showed a negative relationship between new ways of working and the traditional ways of working, and also the comparison of the means of Tables 6 and 7, which are 3.88 and 2.66 respectively, showed that the ways of working preferred by the staff of the General Hospital studied is the traditional ways of working over the new ways of working, though they showed a marginal preference for the new ways of working.

\section{Discussion}

The result of this study is however, expectedly, imbued with the reluctance of the respondents to adopt the changes a new way of working may bring and so they still prefer their current traditional ways of working over the introduction of new ways of working, this is in tune with the findings of Stoffers, Kurstjens, \& Schrijver (2015), who observed that contrary to the theoretical views of Stam (2011), that NWW satisfies employees needs and wishes which can lead to better development of competences necessary for NWW, and that of Baane, Houtkamp \& Knotter (2010), that opined that it can lead to greater staff motivation, Stoffers, Kurstjens, \& Schrijver (2015), however, in their study contrarily concluded that NWW couldn't, even where it is practicalized, offer staff more opportunity to demonstrate 
and develop competences such as responsibility, flexibility and entrepreneurship. This is not surprising because one of the disadvantages of the introduction of "New Ways of Working", according to Stoffers, Kurstjens, \& Schrijver (2015), is that NWW is most often not desirable by staff and usually meets with resistance when it is introduced, but according to Balfour and Clarke (2001) for change to be embraced and sustained, people must identify with and value these changes that new ways of working will bring, especially since there can be extension of staff roles and practice as well as introduction of new roles and which according to UK Department of Health (2007) can come through leadership and development in the context of service developments.

It is heartening that $65.5 \%$ of the respondents have at least a bachelor or higher national diploma degrees, with $13.6 \%$ of them even having a post graduate degree, so also is the existence of about half of the respondents (45.7\%) being below 40 years of age, a situation which means the respondents will be easy to convince of the benefits of the new ways of working, because as Auer and Speckesser (1997) observed, a younger, well-educated and trained work force are commonly required for continuous learning and adaptation in a work environment.

The health service sector in Nigeria requires a more strict organizational process for patient satisfaction to be continually paramount, and like any expected reaction of people to any change, there will be initial dislike and resistance of hospital employees in terms of their independence and flexibility and the wishes of patients' for more flexibility, as well as the ability of these patients to exercise their power of "being in charge", which if not fathomed into the whole essence of NWW, may truncate the fruition of the implementation of NWW in public hospitals in Nigeria, so the preference of the respondents in this study is not unexpected. However, $58 \%$ of the responses of the respondents that constituted those that will actually be involved in the workability of the new ways of working in public hospitals, physiotherapists, doctors, and dentists, in this study, agreed to the introduction of the new ways of working, this sounds gladdening, but not rubbing off the fact that $65 \%$ of their responses still shows preference for the traditional ways of working.

In as much as this study has strived to show that the introduction of new ways of working might not be a totally bad idea going by the responses of the respondents in this study, but it has exposed the fact that more efforts should still be done by more researchers to involve more of these health workers especially those that are actively involved in giving out-patient clinics appointments, and also the study should be extended to involve more public hospitals so as to be able to arrive at a welcoming result that will be generalizable.

\section{Conclusion}

The staff of public hospitals in Nigeria still prefer the traditional ways of working over the traditional ways of working, though it is not melancholic all the way since there is still some level of preference for the new ways of working, and this means that there is still chance of the workability of new ways of working in public hospitals in Nigeria, only if more awareness can be created on the advantages it will bring not only to hospital patients but also to hospital workers. The new ways of working is really imperative in terms of the flexibility it will bring to both the patients and health workers and in the process leads to lessening the tension that often exists between the health workers and the public hospitals on one hand, and that that exist between them and the government that own these public hospitals

\section{Tables}

Table 1. Gender of the respondents

\begin{tabular}{|l|l|l|}
\hline Gender & Number & Percentage \\
\hline Male & 25 & 30.9 \\
\hline Female & 56 & 69.1 \\
\hline Total & $\mathbf{8 1}$ & $\mathbf{1 0 0 . 0}$ \\
\hline
\end{tabular}


Texila International Journal of Public Health

Volume 5, Issue 1, Mar 2017

Table 2. Age range of the respondents

\begin{tabular}{|l|c|c|}
\hline Age & Number & Percentage \\
\hline$<25$ & 1 & 1.2 \\
\hline $26-30$ & 11 & 13.6 \\
\hline $31-35$ & 9 & 11.1 \\
\hline $36-40$ & 16 & 19.8 \\
\hline $41-45$ & 19 & 23.5 \\
\hline $46-50$ & 19 & 23.5 \\
\hline $51-55$ & 5 & 6.2 \\
\hline$>56$ & 1 & 1.2 \\
\hline Total & $\mathbf{8 1}$ & $\mathbf{1 0 0 . 0}$ \\
\hline
\end{tabular}

Table 3. Education level of the respondents

\begin{tabular}{|l|l|l|}
\hline Education & Number & Percentage \\
\hline Secondary School & 2 & 2.5 \\
\hline OND/NCE & 8 & 9.9 \\
\hline School of Nursing & 17 & 21.0 \\
\hline Bachelor/HND & 42 & 51.9 \\
\hline Post Graduate & 11 & 13.6 \\
\hline Others & 1 & 1.2 \\
\hline Total & $\mathbf{8 1}$ & $\mathbf{1 0 0 . 0}$ \\
\hline
\end{tabular}

Table 4. Specialty/Department of the respondents

\begin{tabular}{|l|l|l|}
\hline Specialty/Department & Number & Percentage \\
\hline Nursing & 29 & 35.8 \\
\hline Medical & 11 & 13.6 \\
\hline Dental & 3 & 3.7 \\
\hline Pharmacy & 11 & 13.6 \\
\hline Physiotherapy & 2 & 2.5 \\
\hline $\begin{array}{l}\text { Health Information } \\
\text { Management }\end{array}$ & 5 & 6.2 \\
\hline Laboratory & 6 & 7.4 \\
\hline Account & & 7.4 \\
\hline Administration & 5 & 6.2 \\
\hline Medical Social Worker & 3 & 3.7 \\
\hline Total & $\mathbf{8 1}$ & $\mathbf{1 0 0 . 0}$ \\
\hline
\end{tabular}

Table 5. Job function of the respondents

\begin{tabular}{|l|l|c|}
\hline Job function & Number & Percentage \\
\hline Managerial & 21 & 25.9 \\
\hline Non-managerial & 60 & 74.1 \\
\hline Total & $\mathbf{8 1}$ & $\mathbf{1 0 0 . 0}$ \\
\hline
\end{tabular}

Table 6. Means and standard deviations of opinions on 'New Ways of Working' as the preferred way of working by hospital staff

\begin{tabular}{|l|l|l|l|l|l|l|l|l|l|}
\hline STATEMENT & SA & A & SMA & N & SMD & D & SD & Mean & St \\
& 1 & $\mathbf{2}$ & $\mathbf{3}$ & $\mathbf{4}$ & $\mathbf{5}$ & $\mathbf{6}$ & $\mathbf{7}$ & & \\
\hline $\begin{array}{l}\text { Working hours' } \\
\text { should rather be }\end{array}$ & $\mathbf{7}$ & $\mathbf{2 4}$ & $\mathbf{1 3}$ & $\mathbf{4}$ & $\mathbf{4}$ & $\mathbf{1 5}$ & $\mathbf{1 4}$ & $\mathbf{3 . 9 3}$ & $\mathbf{2 . 1 2}$ \\
\hline
\end{tabular}


Texila International Journal of Public Health

Volume 5, Issue 1, Mar 2017

\begin{tabular}{|c|c|c|c|c|c|c|c|c|c|}
\hline \multicolumn{10}{|l|}{$\begin{array}{l}\text { chosen by each } \\
\text { worker to achieve the } \\
\text { best balance between } \\
\text { work and private } \\
\text { lives. }\end{array}$} \\
\hline $\begin{array}{l}\text { Hospital staff should } \\
\text { be given the } \\
\text { opportunity to work } \\
\text { independently of the } \\
\text { physical walls of the } \\
\text { hospital. }\end{array}$ & $\begin{array}{l}\mathbf{5} \\
(6.2)\end{array}$ & $\begin{array}{l}\mathbf{2 8} \\
(34.6)\end{array}$ & $\begin{array}{l}\mathbf{1 3} \\
(16.1)\end{array}$ & $\begin{array}{l}9 \\
(11.1)\end{array}$ & $\begin{array}{l}\mathbf{5} \\
(6.2)\end{array}$ & $\begin{array}{l}\mathbf{1 3} \\
(16.1)\end{array}$ & $\begin{array}{l}8 \\
(9.9)\end{array}$ & 3.64 & 1.89 \\
\hline \multirow[b]{2}{*}{$\begin{array}{l}\text { Hospital workers } \\
\text { should be given the } \\
\text { freedom to determine } \\
\text { the time of starting } \\
\text { and closing each day } \\
\text { work }\end{array}$} & 3 & 6 & 10 & 6 & 7 & 27 & 22 & 5.19 & 1.80 \\
\hline & (3.7) & (7.4) & (13.6) & (7.4) & $(8.6)$ & (33.3) & $(27.2)$ & & \\
\hline $\begin{array}{l}\text { Social media tools } \\
\text { and virtual interactive } \\
\text { media should rather } \\
\text { be used to attend to } \\
\text { patients health needs. }\end{array}$ & $\begin{array}{l}3 \\
(3.7)\end{array}$ & $\begin{array}{l}\mathbf{1 2} \\
(14.8)\end{array}$ & $\begin{array}{l}\mathbf{2 0} \\
(24.7)\end{array}$ & $\begin{array}{l}9 \\
(11.1)\end{array}$ & $\begin{array}{l}7 \\
(8.6)\end{array}$ & $\begin{array}{l}\mathbf{2 0} \\
(24.7)\end{array}$ & $\begin{array}{l}\mathbf{1 0} \\
(12.4)\end{array}$ & 4.30 & 1.82 \\
\hline $\begin{array}{l}\text { Hospital workers } \\
\text { should be allowed to } \\
\text { choose when to be } \\
\text { physically present at } \\
\text { work and when to use } \\
\text { social media to attend } \\
\text { to patients' needs. }\end{array}$ & $\begin{array}{l}\mathbf{1} \\
(1.2)\end{array}$ & $\begin{array}{l}6 \\
(7.4)\end{array}$ & $\begin{array}{l}\mathbf{1 4} \\
(17.3)\end{array}$ & $\begin{array}{l}5 \\
(6.2)\end{array}$ & $\begin{array}{l}\mathbf{1 1} \\
(13.6)\end{array}$ & $\begin{array}{l}\mathbf{2 6} \\
(32.1)\end{array}$ & $\begin{array}{l}\mathbf{1 8} \\
(22.2)\end{array}$ & 5.11 & 1.71 \\
\hline $\begin{array}{l}\text { The hospital should } \\
\text { be provided with } \\
\text { facilities to attend to } \\
\text { their private patients } \\
\text { within the hospital. }\end{array}$ & $\begin{array}{l}\mathbf{1 0} \\
(11.1)\end{array}$ & $\begin{array}{l}7 \\
(8.7)\end{array}$ & $\begin{array}{l}5 \\
(6.2)\end{array}$ & $\begin{array}{l}\mathbf{8} \\
(9.9)\end{array}$ & $\begin{array}{l}\mathbf{5} \\
(6.2)\end{array}$ & $\begin{array}{l}\mathbf{2 8} \\
(34.6)\end{array}$ & $\begin{array}{l}\mathbf{1 8} \\
(22.2)\end{array}$ & 4.81 & 2.08 \\
\hline $\begin{array}{l}\text { Relevant knowledge } \\
\text { and information } \\
\text { exchanged on virtual } \\
\text { interactive media } \\
\text { should be made use } \\
\text { of by hospital staff in } \\
\text { doing their work }\end{array}$ & $\begin{array}{l}\mathbf{2 3} \\
(28.4)\end{array}$ & $\begin{array}{l}\mathbf{3 7} \\
(45.7)\end{array}$ & $\begin{array}{l}9 \\
(11.1)\end{array}$ & $\begin{array}{l}7 \\
(8.7)\end{array}$ & $\begin{array}{l}\mathbf{0} \\
(0)\end{array}$ & $\begin{array}{l}2 \\
(2.5)\end{array}$ & $\begin{array}{l}3 \\
(3.7)\end{array}$ & 2.28 & 1.41 \\
\hline $\begin{array}{l}\text { Relevant information } \\
\text { on patients' } \\
\text { management should } \\
\text { be easily accessible to } \\
\text { workers when they } \\
\text { attend to patients } \\
\text { outside their } \\
\text { workplace. }\end{array}$ & $\begin{array}{l}\mathbf{3 6} \\
(44.4)\end{array}$ & $\begin{array}{l}\mathbf{3 3} \\
(40.7)\end{array}$ & $\begin{array}{l}\mathbf{6} \\
(7.4)\end{array}$ & $\begin{array}{l}3 \\
(3.7)\end{array}$ & $\begin{array}{l}\mathbf{2} \\
(2.5)\end{array}$ & $\begin{array}{l}\mathbf{0} \\
(0)\end{array}$ & $\begin{array}{l}\mathbf{1} \\
(1.2)\end{array}$ & 1.84 & 1.08 \\
\hline & & & & & & & & 3.88 & 1.73 \\
\hline
\end{tabular}

${ }^{+}$Standard deviation

SA $=$ Strongly Agree, $\mathbf{A}=$ Agree, $\mathbf{S M A}=$ Somewhat Agree, $\mathbf{N}=$ Neutral, $\mathbf{S M D}=$ Somewhat Disagree, $\mathbf{D}=$ Disagree SD $=$ Strongly Disagree 
Texila International Journal of Public Health

Volume 5, Issue 1, Mar 2017

Table 7. Means and Standard deviations of opinions on Traditional Ways of Working as the preferred ways of working by staff

\begin{tabular}{|c|c|c|c|c|c|c|c|c|c|}
\hline Statement & $\begin{array}{l}\text { SA } \\
1\end{array}$ & $\begin{array}{l}\text { A } \\
2\end{array}$ & $\begin{array}{l}\text { SMA } \\
\mathbf{3}\end{array}$ & $\begin{array}{l}N \\
4\end{array}$ & $\begin{array}{l}\text { SMD } \\
5\end{array}$ & $\begin{array}{l}\text { D } \\
6\end{array}$ & $\begin{array}{l}\text { SD } \\
7\end{array}$ & Mean & St $^{+}$ \\
\hline $\begin{array}{l}\text { The present way of } \\
\text { working in the hospital } \\
\text { is producing the } \\
\text { desired results that are } \\
\text { satisfying to both staff } \\
\text { and patients. }\end{array}$ & $\begin{array}{l}\mathbf{2 2} \\
(27.2)\end{array}$ & $\begin{array}{l}\mathbf{2 4} \\
(29.6)\end{array}$ & $\begin{array}{l}\mathbf{1 8} \\
(22.2)\end{array}$ & $\begin{array}{l}\mathbf{5} \\
(6.2)\end{array}$ & $\begin{array}{l}3 \\
(3.7)\end{array}$ & $\begin{array}{l}7 \\
(8.6)\end{array}$ & $\begin{array}{l}2 \\
(2.5)\end{array}$ & 2.65 & 1.63 \\
\hline $\begin{array}{l}\text { The present way of } \\
\text { working in the hospital } \\
\text { is allowing knowledge } \\
\text { and information to be } \\
\text { freely shared amongst } \\
\text { staff }\end{array}$ & $\begin{array}{l}\mathbf{2 1} \\
(25.9)\end{array}$ & $\begin{array}{l}\mathbf{2 1} \\
(25.9)\end{array}$ & $\begin{array}{l}\mathbf{1 8} \\
(22.2)\end{array}$ & $\begin{array}{l}7 \\
(8.6)\end{array}$ & $\begin{array}{l}4 \\
(4.9)\end{array}$ & $\begin{array}{l}9 \\
(11.1)\end{array}$ & $\begin{array}{l}\mathbf{1} \\
(1.2)\end{array}$ & 2.79 & 1.66 \\
\hline $\begin{array}{l}\text { The present } 8 \text { am to } \\
4 \mathrm{pm} \text { working hour } \\
\text { routine in the hospital } \\
\text { is very appropriate and } \\
\text { satisfies both patients } \\
\text { and staff. }\end{array}$ & $\begin{array}{l}\mathbf{1 2} \\
(14.8)\end{array}$ & $\begin{array}{l}\text { 30 } \\
(37.0)\end{array}$ & $\begin{array}{l}\mathbf{1 7} \\
(21.0)\end{array}$ & $\begin{array}{l}9 \\
(11.1)\end{array}$ & $\begin{array}{l}7 \\
(8.6)\end{array}$ & $\begin{array}{l}\mathbf{6} \\
(7.4)\end{array}$ & $\begin{array}{l}\mathbf{0} \\
(0)\end{array}$ & 2.84 & 1.44 \\
\hline $\begin{array}{l}\text { Patients coming to the } \\
\text { clinic physically for } \\
\text { their appointments is } \\
\text { convenient for both } \\
\text { staff and patients. }\end{array}$ & $\begin{array}{l}19 \\
(23.5)\end{array}$ & $\begin{array}{l}37 \\
(45.7)\end{array}$ & $\begin{array}{l}\mathbf{1 2} \\
(14.8)\end{array}$ & $\begin{array}{l}4 \\
(4.9)\end{array}$ & $\begin{array}{l}4 \\
(4.9)\end{array}$ & $\begin{array}{l}\mathbf{5} \\
(6.2)\end{array}$ & $\begin{array}{l}\mathbf{0} \\
(0)\end{array}$ & 2.41 & 1.36 \\
\hline \multirow[t]{2}{*}{$\begin{array}{l}\text { The hospital } \\
\text { requirement for } \\
\text { workers to be } \\
\text { physically present at } \\
\text { work between } 8 \text { am and } \\
4 \text { pm is achieving the } \\
\text { best result for both } \\
\text { staff and patients. }\end{array}$} & $\begin{array}{l}\mathbf{1 5} \\
(18.5)\end{array}$ & $\begin{array}{l}\mathbf{3 3} \\
(40.7)\end{array}$ & $\begin{array}{l}\mathbf{1 7} \\
(21.0)\end{array}$ & $\begin{array}{l}6 \\
(7.4)\end{array}$ & $\begin{array}{l}\mathbf{5} \\
(6.2)\end{array}$ & $\begin{array}{l}4 \\
(4.9)\end{array}$ & $\begin{array}{l}\mathbf{1} \\
(1.2)\end{array}$ & 2.62 & 1.41 \\
\hline & & & & & & & & 2.66 & 1.27 \\
\hline
\end{tabular}

${ }^{+}$Standard deviation

$\mathbf{S A}=$ Strongly Agree, $\mathbf{A}=$ Agree, $\mathbf{S M A}=$ Somewhat Agree, $\mathbf{N}=$ Neutral, $\mathbf{S M D}=$ Somewhat Disagree, $\mathbf{D}=$ Disagree, $\mathbf{S D}=$ Strongly Disagree

\section{References}

[1]. Al-Tawfiq JA, Memish ZA: What are our pharmacotherapeutic options for MERS-CoV?. Expert Rev Clin Pharmacol. 2014, 7: 235-238. 10.1586/17512433.2014.890515.

[2]. Auer, P. \& Speckesser, S. (1997). Labour markets and organizational change: Future working structures for an ageing work force. Journal of Management \& Governance 1: 177. doi:10.1023/A:1009915203329

[3]. Baane, R. H., Houtkamp, p., Knotter, M., (2010). Het nieuwe werken ontrafeld [New ways of working figured out]. Assen: Koninklijke Van Gorcum.

[4]. Balfour M, \& Clarke C (2001) Searching for sustainable change. Journal of Clinical Nursing; 10: 1, 44-50. 
[5]. Bijl, D., (2007). Het nieuwe werken: Op weg naar een productive kenniseconomie [New Ways of working: heading for a productive knowledge economy]. Den Haag: Sdu Publishers bv.

[6]. Bijl, D., (2009). Aan de slag met het nieuwe werken [Let's get to the new ways of working]. Zeewolde: Par CC.

[7]. Blok, M. M., Groenesteijn, L., Schelvis, R., \& Vink, P. (2012). New ways of working: does flexibility in time and location of work change work behavior and affect business outcomes? Work: A Journal of Prevention, Assessment and Rehabilitation, 41, 5075-5080.

[8]. Bryman, A., \& Bell, E. (2011). Business Research Methods (3rd edition). New York: Oxford University Press Inc.

[9]. Cameron, K. S., \& Quinn, R. E., (2008). Onderzoeken en veranderen van organizatiecultuur [Researching and changing organizational culture]. Den Haag: Sdu Publishers bv.

[10]. Cronbach L.J., (1951) Coefficient alpha and the internal structure of tests. Psychometrika. 16:297-334.

[11]. De Leede, J., \& Kraijenbrink, J. (2014). The Mediating Role of Trust and Social Cohesion in the Effects of New Ways of Working: A Dutch Case Study. Human Resource Management, Social Innovation and Technology (Advanced Series in Management, Volume 14). England. Emerald Group Publishing Limited, 14, 3-20.

[12]. Egmond van, H., (2010). Het nieuwe werken: Van visie naar praktijk [New ways of working: From vision to practice]. Alphen aan den Rijn: Kluwer.

[13]. Gautret P, Benkouiten S, Salaheddine I, Belhouchat K, Drali T,\& Parola P., (2013). Hajj pilgrims knowledge about Middle East respiratory syndrome coronavirus, August to September 2013. Euro Surveill. 2013, 18: 20604.

[14]. Haterd van de, B., (2010). Werken nieuwe stijl [Working on a new style]. Amersfoort: A.W. Bruna Publishers B.V.

[15]. Heuver, P. (2015). Building a bridge between new ways of working and leadership. A Master of Business Administration Thesis. Enschede: University of Twente.

[16]. Keuning, D., (2007). Structuur doorzien [Structure seen]. Groningen: Wolters Noordhoff.

[17]. Kotler, P., Kartajaya, H., \& Setiawan, I., (2010). Marketing 3.0: Vind de klik met je klant [Marketing 3.0: From products to customers to the human spirit]. Den Haag: Sdu Publishers bv.

[18]. Kuipers, H., Amelsvoort, P., \& Kramer, E.H., (2010). Het nieuwe organisatie: Alternatieven voor de bureaucratie [New ways of organizing: Alternatives for bureaucracy]. Leuven: Acco.

[19]. Memish ZA, Al-Tawfiq JA, Makhdoom HQ, Al-Rabeeah AA, Assiri A, Alhakeem RF, Alrabiah FA, Alhajjar S, Albarrak A, Flemban H, Balkhy H, Barry M, Alhassan S, Alsubaie S, \& Zumla A., (2014). Screening for Middle East respiratory syndrome coronavirus infection in hospital patients and their healthcare worker and family contacts: a prospective descriptive study. Clin Microbiol Infect. 2014, 20: 469-474. 10.1111/1469-0691.12562.

[20]. Pierik, C., (2009). Talent management: Hét middel om vitaal te blijven [Talent management: the tool to remain vital]. Het Grootste Vaktijdschrift over Bedrijfsgezondheid [The largest magazine about organizational health], nr. 5, 8-11.

[21]. Stam, P., (2011). Het nieuwe werken meegewogen [New ways of working weighed in]. Utrecht: Utrecht University.

[22]. Stoffers J., Kurstjens J., \& Schrijver I.(2015). Leadership and New Ways of Working: A Case Study in a Financial Service OrganiZation. International Journal of Business and Economics Research. Vol. 4, No. 3, 2015, pp. 157-162. doi: 10.11648/j.ijber.20150403.18

[23]. UK Department of Health (2010). Responsibility and accountability: Moving on for new ways of working to a creative, capable workforce best practice guidance. London: UK Department of Health, $2010 . \quad$ Retrieved from: http://www.rcpsych.ac.uk/pdf/Responsibility\%20and\%20Accountability\%20Moving\%20on\%20for\%2 0New\%20Ways\%20of\%20Working\%20to\%20a\%20Creative, \%20Capable\%20Workforce.pdf

[24]. Volberda, H., Jansen, J., Tempelaar, M., \& Heij, K., (2011). Monitoren van sociale innovatie: Slimmer werken, dynamisch managen en flexible organiZeren: Monitoring social innovation: working smarter, dynamic management and organiZing flexible. Magazine for HRM, 1, 85-110. 
Texila International Journal of Public Health

Volume 5, Issue 1, Mar 2017

[25]. Wensing, L., (2009). Technologie is en blijft de sleutel tot het nieuwe werken [Technology is and remains the key to New

[26]. Ways of Working]. Retrieved from: http://hetnieuwewerkenblog.nl/technologie-sleutelhetnieuwe- werken/ 